\title{
DEMOCRACIA DEBILITADA: A ASCENSÃO DO FASCISMO \\ NO BRASIL
}

\author{
DEMOCRACIA DEBILITADA: EL ASCENSO DEL FASCISMO EN
}

BRASIL

\section{DEBILITATED DEMOCRACY: THE RISE OF FASCISM IN BRAZIL}

\author{
Joana A. Coutinho \\ Universidade Federal do Maranhão, São Luís, Maranhão, Brasil \\ ORCID: https://orcid.org/0000-0002-8846-6491 \\ ID Lattes: http://lattes.cnpq.br/1089256440314557 \\ Endereço eletrônico: joaninhacoutinho@ hotmail.com
}

DOI: $10.22481 /$ rbba.v10i01.8765

\begin{abstract}
RESUMO
Este artigo busca analisar a fragilidade da democracia brasileira que se agudiza com a eleição do capitão do exército, reformado, Jair Bolsonaro, com claras inclinações ao fascismo. Nossa questão central, é tentar desvelar a construção desse fenômeno e, como, de certa maneira o desprezo do campo da esquerda para uma "privatização da vida pública e uma publicização da vida privada", num processo declarado de avanço do conservadorismo na sociedade brasileira.
\end{abstract}

Palavras-chave: Fascismo; $\quad$ Conservadorismo; Democracia.

\section{RESÚMEN}

Este artículo busca analizar la fragilidad de la democracia brasileña, agravada por la elección del capitán del ejército retirado, Jair Bolsonaro, con claras inclinaciones al fascismo. Nuestro tema central es tratar de desvelar la construcción de este fenómeno y, en cierto modo, el desprecio del campo de izquierda por una "privatización de 
la vida pública y una publicidad de la vida privada", en un proceso declarado de avance del conservadurismo en la sociedad brasileña.

Palabras Clave: Fascismo; Conservatismo; Democracia.

\begin{abstract}
S
This article seeks to analyze the fragility of Brazilian democracy that is aggravated by the election of the retired army captain, Jair Bolsonaro, with clear inclinations to fascism. Our central question is to try to bring up the construction of this phenomenon and, in a way, the contempt of the left field for a "privatization of public life and a publicization of private life", in a declared process of advancing conservatism in Brazilian society.
\end{abstract}

Keywords: Fascism: Conservatism; Democracy.

\title{
INTRODUÇÃO
}

Pensar a questão da democracia é um tema ao mesmo tempo simples e complexo. Pois bem, carece fazermos uma retrospectiva histórica para podermos entender o significado mais estreito da democracia. Para isso, dividirei este texto em quatro partes: 1) discutir o significado e o conceito da democracia (numa breve retrospectiva histórica; 2) A crise da democracia representativa e 3) a democracia no Brasil e o que chamo de ascensão do fascismo no país e 4) os desafios para a construção de uma democracia radical e real.

\section{UMA BREVE DISCUSSÃO SOBRE A DEMOCRACIA}

Quando falamos de democracia antiga, nos remota aos gregos, mais especificamente Atenas, apontada como exemplo de democracia, mas também associada ao trabalho escravo. Estima-se que a população escrava ficava entre 80.000-100.000 (HELD,1987, p.21). Cidadãos em Atenas eram homens, maiores de 20 anos, mulheres, imigrantes, e escravos obviamente não participavam da vida pública. A democracia antiga "era uma democracia dos patriarcas". A economia escravista, como assevera, Held (1987) cria tempo "livre" para os cidadãos. Finley (1988, p.28) ao discutir o argumento de que no demos ateniense a grande maioria dos escravos estava excluída, pondera que, no entanto, "ela incentivava uma atitude aberta, franca sobre 
exploração, por exemplo e uma justificativa para a guerra”. No entanto, diz ele, grande parte do demos, camponeses, comerciantes e artesãos eram considerados cidadãos

lado a lado com os instruídos das classes mais altas. A integração de tais pessoas na comunidade política, como membros participantes, novidade estarrecedora para a época e raramente repetida daí por diante, resgata parte a importância da democracia antiga, por assim dizer. (FINLEY, 1988, p.29).

Ellen Wood adverte que não podemos associar, meramente, o trabalho escravo, como a base pilar da democracia ateniense, mas que há também, a presença do trabalho livre, fundamento essencial para o desenvolvimento do capitalismo (WOOD, 2003). O "trabalho livre era a espinha dorsal da democracia ateniense" (idem, p.159). Não se trata, segundo argumento da autora, de minimizar a "importância da escravidão na sociedade ateniense", mas de colocar o trabalho livre "pelo menos no mesmo nível em termos de capacidade explicativa" (WOOD, 2003, p.160). O trabalho livre, como se sabe, é a base da fundação do Estado burguês.

O Estado burguês define todos os homens independentemente de sua posição no processo social de produção (classe exploradora, classe explorada), como capazes de praticar atos de vontade (SAES, 1985, p.50). Atribui a todos os homens (independentemente da classe social a que pertence) capacidade jurídica, transformando-os em sujeitos individuais de direitos e deveres (cidadãos no plano civil), e o recrutamento para a sua burocracia de Estado é formalmente aberto a todas as classes sociais. O Estado burguês trata igual aos desiguais e com isso produz um duplo efeito político e ideológico sobre a classe explorada: 1) o efeito de isolamento (individualização de seus membros); 2) representação de unidades (reunificação subjetiva desses homens já "individualizados" numa comunidade imaginária: o povo-nação.

Cabe aqui, uma pequena, mas esclarecedora distinção. Quando falamos de cidadania, nos remete a pensar a classificação feita por Marshall, no clássico, Cidadania e classe social. Neste livro, o autor concebe a cidadania como um status concedido àqueles que são membros integrais de uma comunidade e composta por três elementos: civil, político e social. O elemento civil seria composto pelos direitos à liberdade individual (liberdade de ir e vir), de se expressar, e, obviamente, o direito à propriedade. No elemento político, o direito de participar do exercício do poder político, inclusive como um eleitor; no social, o direito a um mínimo de bem-estar econômico e segurança, de acordo com os padrões que prevalecem na sociedade (MARSHALL, 1963, p.63-64). 
Não é demais repetir que o Estado burguês, qualquer que seja sua forma (democrática ou ditatorial), converte todos os homens "independentemente de sua posição no processo social de produção, em cidadãos no plano civil; mas só o Estado democrático-burguês concede a todos os homens a cidadania propriamente política" (SAES, 1987, p.87).

A leitura de Saes nos permite pensar a formação social brasileira e a característica que funda a nossa democracia e cidadania. Aqui, onde imperou por largo tempo, o coronelismoi , ou seja, a relação privada e pública se mesclava, nesse momento, como parte de uma mesma ordem. Assim, a relação pessoal ganha

ganha um caráter político novo no quadro de um Estado burguês-democrático, por duas razões: a) o Estado burguês, quando assume a forma democrática, converte a participação eleitoral num dos aspectos mais visíveis atraentes da cidadania, e utiliza o processo eleitoral para atomizar as classes trabalhadoras e representar a unidade do Povo-Nação; b) em todos os Estados burgueses democráticos, uma parte (variável no tempo e no espaço) da população eleitoral está sediada no campo [...] Dissemos acima que o coronelismo implica uma capacidade de manipulação eleitoral das massas das áreas précapitalistas do campo. Isso não significa, todavia, que o verdadeiro objeto das práticas do coronelismo sejam os trabalhadores do campo sujeitos a uma relação de dominação e dependência pessoal. Na verdade, tais práticas objetivam iludir politicamente e tolher eleitoralmente outras classes trabalhadoras: sobretudo as classes trabalhadoras urbanas, mas igualmente o proletariado rural (dependendo, a extensão deste, do grau de destruição das relações de produção pré-capitalistas no campo). Em suma, as massas do campo pré-capitalista não são o objeto e sim o instrumento do coronelismo. (SAES, 1987, p.87-88).

Essas observações são importantes para podermos ter uma melhor compreensão da constituição da nossa cidadania e as bases nas quais a democracia brasileira se constituiu. $\mathrm{O}$ que leva a Carvalho (2002) a afirmar que a lógica do Marshall, no Brasil, dá se de forma invertida. Ou seja, aqui, a cronologia e a lógica da sequência descrita por Marshall seguiram outros caminhos com uma ordem inversa. Primeiro, os direitos sociais implantados em períodos de supressão dos direitos políticos e redução dos direitos civis. E, ainda, hoje, os direitos civis continuam inacessíveis para a maioria da população. Segundo Carvalho, isso gerou uma relação em que a ação política, no Brasil, é orientada para a negociação direta com o governo, sem passar pela mediação da representação, o que ele chama de "estadania ii". Essa "estadania" é reveladora da "fragilidade" da nossa democracia. Estes elementos são importantes para ajudar a pensar os momentos de ruptura da ordem democrática-burguesa (referimo-nos a 64, com o Golpe Militar) e também a 2016 com o impedimento (sem bases legais) da Presidente eleita, 
pelo Partido dos Trabalhadores em 2014. Não pretendemos neste curto espaço de tempo, fazer uma análise sobre os governos progressistas na América Latina, e, em particular do PT no Brasil, mas tão somente assinalar a ruptura da ordem democrática.

\section{A CRISE DA DEMOCRACIA REPRESENTATIVA: A DEMOCRACIA EM FRANGALHOS}

Um país fraturado foi o resultado das últimas eleições no Brasil, desde a eleição de 2014 até a eleição de 2018 que sai vitorioso um político que, em tese, nega a política. Este não é fenômeno recente da política brasileira, tivemos no passado pelo menos dois presidentes eleitos sob a pecha do "novo, o diferente, o não político" que foram desastrosos para o país. Mas, este, sobre muitos aspectos é bem pior, porque nos leva de volta ao passado, que muitos desejariam esquecer. Os primeiros foram Jânio Quadros (1961-1963), o segundo, o caçador de marajás ele mesmo um — o Fernando Collor de Melo (1989-1992) e o terceiro um ex-miltar, reformado com currículo pouco recomendado nas Forças Armadas, que se aventura na vida política, há 27 anos, cujo êxito foi colocar toda sua família para viver "da política" como definiria Max Weberiii.

Ao apresentar-se como o candidato antissistema, com um discurso conservador que remete a construção de um país, como também de uma família, tradicional, ordeira, defensora dos "bons costumes", contra a corrupção — que dá a razão para o Golpe orquestrado em 2016 contra a presidente eleita, Dilma Rousseff - Jair Messias Bolsonaro logrou ganhar as eleições. Angariou votos de todas as camadas sociais, um fenômeno a estudar com rigor. Explicamos: o seu discurso foi (é) abertamente conservador e autoritário; desperta e alimenta o ódio contra os negros, nordestinos, mulheres, homossexuais e, claro, todos os que estão no espectro da esquerda: democratas, socialistas, comunistas, traduzido e alimentado por um antipetismo visceral.

O que carece de aprofundamento analítico é como a construção de um "inimigo interno", heterógeno, plural, toma forma de tal maneira que o "ódio ao PT" torna-se maior que o "amor a democracia ${ }^{\text {iv" }}$ e a luta contra a "corrupção", materializada com uma ação da polícia federal e do Ministério Público (Lava Jato) levou milhões de eleitores optarem por um governo que declaradamente busca retirar direitos conquistados a duras penas de toda a sociedade brasileira. Temos algumas hipóteses que apresentamos neste pequeno artigo. Uma delas, consiste nos fatores que se não explica completamente, justifica em momentos de crise estrutural do 
capitalismo, uma certa ideologia do "empreendedorismo" que abarca as classes populares. Foi amplamente desenvolvida no Brasil a partir dos anos 1980 e acelera muito rapidamente seu crescimento nos anos 2000: as igrejas neopentecostais. Um outro fator, não menos importante para essa análise, trata-se de um sentimento — não importa se real— de parte da classe média que assustada, ainda, com o espectro do comunismo (que não ronda o Brasil) mas que mobiliza para o desenvolvimento de um sentimento rancoroso com as classes populares - um eterno sentimento de inferioridade que alimenta um desprezo grande pelos de baixo, e submissão aos de cima. E, por último, os erros dos governos do PT que refletiram em toda a esquerda e, a incapacidade da esquerda em dialogar com estes setores.

\section{O GOLPE DE 2016: "COM O SUPREMO, COM TUDO"}

O golpe de estado, impetrado em 2016, deve ser compreendido em sua plenitude com as grandes manifestações de rua, contra a corrupção, em 2013. Começa com um protesto contra os aumentos das passagens de ônibus em São Paulo, organizados pelo MPL- Movimento Passe Livre - e que rapidamente se espalhou pelo país. A partir daí grandes manifestações, por mais saúde, mais escolas, com "padrão fifa" se intensificaram pelo país. A Rede Globo de televisão, primeiramente, critica do movimento ("são somente 20 centavos") consegue deslumbrar aí o grande potencial dessas manifestações e canalizá-las para seus interesses. Uma oportunidade de ouro para a direita, a resposta dos governantes é rápida e dura de criminalização do movimento. Começa uma grande campanha contra a presidente Dilma Rousseff e o governo do PT. Durante semanas, o país conviveu com manifestações diárias que logo se transformaram em manifestações anti-partidos políticos ou anti-petistas, obrigando o MPL a abandonar as manifestações ${ }^{\mathrm{v}}$.

Estava ali em disputa, duas concepções de manifestações: uma, organizada de baixo para cima, protagonizada pelo MPL; a outra, uma pauta que veio de cima para baixo, a "pauta da massa" (SECCO,2013). O que é importante destacar é que a

Pauta massificada nasce de baixo apenas aparentemente. Num universo de simulacros desprendidos de suas bases, em que os indivíduos relacionam-se diretamente sem mediações visíveis, os manifestantes virtuais não canalizam seu descontentamento pela representação política. Assim, ela se reduz a uma crítica generalizada dos próprios políticos profissionais, mas não do modo de produção da política, enredando-se num emaranhado abstrato (SECCO, 2013, p. 72). 
Uma leitura tendenciosa, coloca essa massa de manifestantes ${ }^{\mathrm{vi}}$ todos supostamente como parte da direita; mas era sobretudo um sinal claro de grande insatisfação, principalmente entre os mais jovens, com os rumos do governo de Dilma Rousseff. E, que claro, num segundo momento, é tomado pela direita que culmina, como assinala Secco, a uma crítica abstrata a todos os "políticos", uma repulsa a todas as bandeiras que que no imaginário reporta a organização de esquerda.

É necessário frisar aqui, que os "anos gloriosos" do Partido dos Trabalhadores haviam chegado ao fim. Dilma Roussef não logrou encontrar todas as condições externas e internas que permitiram os governos de Lula da Silva (2003-2010) grande êxito ao contemplar os pobres com políticas sociais focais, localizadas, numa sociedade extremamente desigual; e, ao mesmo tempo, satisfazer a sede incontrolável por mais lucros do grande capital, principalmente o financeiro. Não é demasiado recordar a "carta aos brasileiros" que sinalizava ao mercado que o governo do PT e de Lula, não iria mudar nenhuma política estrutural do Estado brasileiro. Durante os anos de boom das commodities, dos ventos favoráveis da economia internacional, nada afetou o governo. Não por falta de tentativas. A primeira delas foi o que ficou conhecido como "mensalão"vii. Ou seja, financiamentos não declarados de campanhas políticas, em 2006, que ao satisfazer ao baixo clero, garantia a aprovação de projetos de interesse do governo. Tentativa frustrada já que Lula da Silva, mantinha alta popularidade e a direita não havia, neste momento, criado alternativa palatável.

André Singer (2012, p.52), traz um retrato do que ele nominou de lulismo:

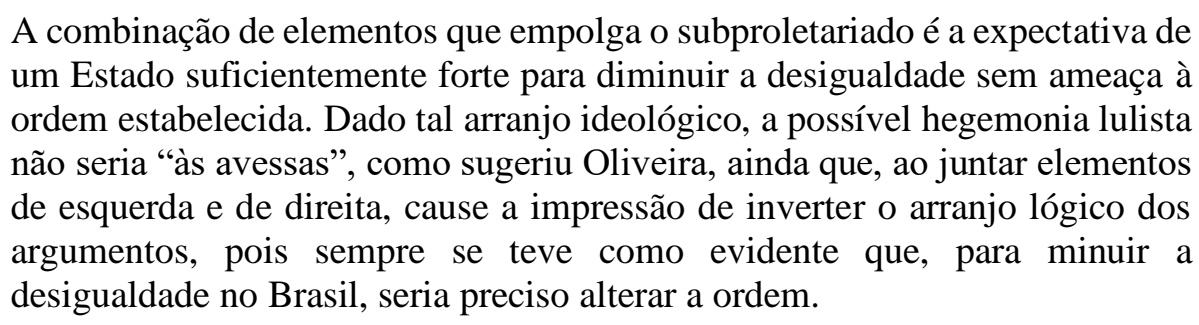

A percepção do movimento profundo que ocorreu em 2006 foi dificultada porque ele cedeu sem mobilização e "sem fazer-se notar". O silêncio causado pela desmobilização provocou confusão a direita e a esquerda. Dez meses antes da reeleição, a revista Veja publicava que Lula seria derrotado porque, de acordo com pesquisa do Ibope, $40 \%$ do apoio obtido em 2002 tinha se esfumado e a "política assistencialista" não conseguiria segurar o eleitor de baixa renda. 
A política neodesenvolvimentista, implementada pelos governos do PT, permitiu que o capitalismo brasileiro voltasse a apresentar taxas de crescimento mais altas. O Banco Nacional de Desenvolvimento Econômico e Social (BNDES) foi o principal financiador da expansão do capital. Destaca-se que as empresas brasileiras, neste momento, estão integradas ao capitalismo internacional e uma classe dominante que não se comove com o apelo nacionalista (BOITO, 2012). Com a crise política, o cenário muda radicalmente e o PT não responde mais as expectativas das classes dominantes, embora essa não consiga apresentar um candidato com capacidade de mobilizar as massas e garantir a vitória nas eleições. As eleições de 2014 foram emblemáticas: com todo esse panorama, Dilma Rousseff saiu vencedora nas urnas, mas sem as condições para implementar o programa apresentado durante sua campanha. Uma campanha marcada pela profunda divisão de um país, não era incomum encontrar cartazes nas ruas com o slogan: o "gigante acordou". De fato, nunca estivemos deitados em um berço esplêndido. Mantivemos a escravidão por mais de 350 anos, herança que preservamos sobretudo no trabalho doméstico. Não é demais recordar que durante as manifestações contra o governo Dilma cartazes com os dizeres "não posso mais pagar a empregada doméstica" era explicitado sem cerimônia, marca dessa herança que consome, sobretudo a classe média brasileira:

(...) o ódio ao pobre hoje em dia é a continuação do ódio devotado ao escravo de antes. Quando as classes médias indignadas saíram às ruas a partir de junho de 2013, não foi certamente, pela corrupção do PT, já que os revoltados ficaram em casa quando a corrupção dos outros partidos veio à tona (SOUZA, 2017. p.67).

A desculpa para o Golpe/impeachment foi construída e em agosto de 2016 é dado a pá de cal para enterrar o governo e demonizar ainda mais as políticas implementadas pelo PT. Contra a "corrupção", "pela família”, "por Deus", e o que não é obviamente declarado: pelos interesses dos Estados Unidos no Pré-Sal, contra a política externa voltada para um fortalecimento das relações com a América Latina; contra os BRICs. Ademais, o Golpe vai penetrando o mais profundo possível na vida cotidiana, na cultura. A criação de um movimento que se auto intitula "Escola sem Partido", que na verdade é um cerceamento da liberdade de cátedra do professor, e proibição de temas que possam despertar qualquer senso crítico. A razão apresentada: doutrinação marxista nas escolas desde o secundário até a Universidade. Uma mentira contada por milhares de vezes, torna-se verdade, como sentenciou Joseph Goebbels. Embora saibamos que essa "verdade" esteja muito longe da Verdade. O abandono de uma ciência totalizante, universal, que deu espaço para os temas da pós-modernidade, as causas 
identitárias, de forma geral, são temas para um artigo a parte ${ }^{\text {viii }}$. Por ora, tentamos entender o avanço do conservadorismo na sociedade brasileira que abala os alicerces da democracia representativa e suas instituições.

\section{O PAPEL DAS IGREJAS NEOPENTECOSTAIS: O AVANÇO DO CONSERVADORISMO}

Não é pretensão dar conta deste fenômeno, na sociedade brasileira nos últimos anos. Uma faceta de uma religião mercantil. As principais seitas dos neopentecostais são donos de meios de comunicação, como rádio e televisão. Avança num campo onde a igreja católica mais secularizada vai perdendo espaço. Sua marca mais profunda está em alentar o sofrimento humano com base numa "teologia da prosperidade" e na "meritocracia". Segundo Mariano (2011, p. 23), "para compreender o porquê o pentecostalismo cresce entre os estratos mais pobres e socialmente mais vulneráveis da população, cumpre investigar como se organiza para convertê-los, o que lhes promete e, como se vincula a seus interesses".

Com discurso de que religião e política são distintas, investem na representação política. O presidente do Brasil, Jair Bolsonaro, contou com amplo apoio do voto evangélico, defendendo uma pauta conservadora na qual o combate o aborto e o casamento entre o mesmo sexo. A intensa campanha nos cultos religiosos de igrejas como a Universal, Renascer em Cristo e dezenas de outras apresentavam o, então, candidato como a única alternativa possível. Como o "Messias", capaz de sacar o cidadão comum, da vulnerabilidade em que vive: violência cotidiana, desemprego, etc. Aqui, não se trata da racionalidade, mas de um discurso mítico, profético; embora falso. A saída para a falta de segurança é mais violência. Toda sua campanha foi baseada na ameaça de exterminar todos aqueles que pensam diferente: os "comunistas", "vermelhos", "petistas", entendido estes como sinônimo de corrupção. É neste contexto que podemos compreender o crescimento de forma veloz de um candidato inexpressivo, medíocre, cuja estratégia principal consistiu em fugir dos debates públicos e usar falsas notícias como maneira de amedrontar as pessoas contra um perigo irreal, imaginário. Quais razões nos levaram a este trágico cenário? Podemos fazer um exercício analítico e especulativo para compreender porque depois de 13 anos de um governo do Partido dos Trabalhadores, com algumas políticas de inclusão social, de ampliação das universidades públicas; de uma política voltada ao continente latino-americano, tem uma viravolta tão significativa na sociedade 
brasileira? Em primeiro lugar a inclusão social não acompanhou uma politização e conscientização da sociedade. Os princípios norteadores não foram da educação no sentido mais amplo do termo, como a ele se referia Paulo Freire (demonizado pelos conservadores). A ideia de Freire de uma educação emancipadora é assustadora, porque parte do princípio de que o pensamento crítico deve ser desenvolvido na escola.

Uma crítica permanente aos desvios fáceis com que somos tentados, às vezes ou quase sempre, a deixar as dificuldades que os caminhos verdadeiros podem nos colocar. Mulheres e homens, seres histórico-sociais, nos tornamos capazes de comparar, de valorar, de intervir, de escolher, de decidir, de romper, por tudo isso, nós fizemos seres éticos. Só somos porque estamos sendo. Estar sendo é a condição, entre nós, para ser. Não é possível pensar os seres humanos longe, sequer, da ética, quanto mais fora dela. Estar longe ou pior, fora da ética, entre nós, mulheres e homens é uma transgressão. É por isso que transformar a experiência em puro treinamento técnico é amesquinhar o que há de fundamentalmente humano no exercício educativo: o seu caráter formador (FREIRE, 1996, p.15).

As conquistas não foram apresentadas como bens coletivos, para o conjunto da população. A pesquisa da socióloga, Esther Solano (2018, p.3), corrobora o argumento desenvolvido aqui:

A deterioração da conciliação lulista, uma imprensa hegemônica oligopolizada que, com frequência, se comporta mais como panfleto político do que como órgão informativo, a complicada governabilidade num Congresso com grande pulverização partidária e de matriz política conservadora, a absoluta falta de respeito com o processo democrático que muitos representantes políticos demonstraram ter, são fatores que intensificaram a crise política, em paralelo à crise econômica que o país atravessa e que é outro fator fundamental para entender o mal-estar social brasileiro.

É neste terreno que vai crescer a ideia da escola como espaço de "doutrinação" de esquerda. Paulo Freire (1996, p 16) acerta quando afirma que

Divinizar ou diabolizar a tecnologia ou a ciência é uma forma altamente negativa e perigosa de pensar errado. De testemunhar aos alunos, às vezes com ares de quem possui a verdade, rotundo desacerto. Pensar certo, pelo contrário, demanda profundidade e não superficialidade compreensão e na interpretação dos fatos. Supõe a disponibilidade à revisão dos achados, reconhece não apenas a possibilidade de mudar de opção, de apreciação, mas o direito de fazê-la. Mas como não há pensar certo à margem de princípios éticos, se mudar é uma possibilidade e um direito, cabe a quem muda - exige o pensar certo - que assuma a mudança operada. Do ponto de vista do pensar certo não é possível mudar e fazer de conta que não mudou. É que todo pensar certo é radicalmente coerente. 
Não é necessária muita imaginação para concluir que a doutrinação vem por parte dos que lhes dizem combater. Um macarthismo ${ }^{\text {ix }}$ a brasileira se instala, antes mesmo da posse do novo presidente: alunos alinhados à extrema direita denunciando professores; panfletos apócrifos acusando professores de "doutrinadores, marxistas, esquerdistas, petistas" e ameaçando suas vidas e seus trabalhos. A luta pela liberdade de cátedra, tornou-se hoje, ponto central da resistência ao novo regime que se instala. O curioso está no fato de que os temas centrais das ciências sociais, para dar um exemplo, estão longe de ser dominados pela teoria marxista.

O foco está sobretudo nas questões identitárias: gênero, etnia, sexualidade. Temas apoderados pelos pós-modernos. O indivíduo desassociado da sua identidade coletiva, de sua identidade de classe. O sujeito pós-moderno, não tem uma identidade "fixa, essencial ou permanente". Essa identidade é "formada e transformada continuamente em relação às formas pelas quais somos representados ou interpelados em sistemas culturais que nos rodeiam" (HALL, 1992, p.13). Assumimos "identidades diferentes em diferentes momentos, que não são unificadas ao redor de um 'eu' coerente" (idem). Hall dá uma chave interessante para compreendermos este movimento. Ou seja, o problema central aqui, não está na nossa compreensão, no fato de termos "muitas identidades", mas principalmente porque essas identidades não estão unificadas ao “redor de um 'eu' coerente. Dentro de nós há identidades contraditórias, empurrando em diferentes direções, de tal modo que nossas identificações estão sendo continuamente deslocadas" (HALL, 1992, p. 13). A consequência desse sujeito pósmoderno, é a formação de uma identidade fragmentada, contraditória, inacabada. Então, a questão étnica ou de gênero camufla, na verdade a centralidade da disputa do conflito de classes e no interior da classe. Não significa dizer que a classe trabalhadora não tenha sexo, nem cor, ou que o seu lugar de origem, não influa nesta relação. No caso brasileiro, a maioria negra, forma o grande contingente dos pobres. Portanto, a luta contra o racismo, o sexismo, se torna extremamente importante na luta contra a opressão, dominação e humilhação. A onda conservadora na qual navega Bolsonaro e seus seguidores, entraram com todas as armas na chamada "guerra cultural". Trata-se "dentre outras coisas, de uma reação (e de um reacionarismo) aos avanços liberais em pautas relacionadas a minorias e a controvérsias morais" (Gomes, 2018, s/p). O papel das mulheres, principalmente no primeiro turno, merece destaque. 


\section{O FASCISMO TUPINIQUIM}

O discurso de ódio alimentado por Jair Messias Bolsonaro deve ser melhor estudado e analisado. Em momentos de crise econômica, a crise política e moral, na sociedade parece aflorar. Marx, no 18 Brumário de Luis Bonaparte, demostra como a Luta de classes na França, criou circunstâncias e condições que permitiram a um personagem medíocre e grotesco desempenhar o papel de herói. A questão que Marx (2011, p.32) se coloca é como "uma nação de 36 milhões de pessoas pôde ser surpreendida por três cavaleiros industriais e por eles se levado ao cativeiro sem oferecer resistência". Claro que a questão central é a crise de hegemonia que a fração da classe dominante no poder não consegue mais apresentar-se como portadora da vontade de toda a sociedade. Apresenta-nos também como o proletariado

parisiense ainda se comprazia na contemplação da ampla perspectiva que se lhe descortinara e se entregava a discussões bem-intencionadas sobre os problemas sociais, os velhos poderes da sociedade se reagruparam, reuniramse, ponderaram e receberam o apoio inesperado da massa da nação, dos camponeses e pequeno-burgueses, os quais se lançaram todos de uma só vez à arena política após a queda das barreiras da Monarquia de Julho (MARX, 2011, p.33).

Parece claro que os 57 milhões de eleitores de Bolsonaro não são todos fascistas, mas caiu no canto das respostas fáceis aos seus dramas cotidianos. Adepto da ditadura militar, defensor de torturador confesso, ameaça abertamente todos os que se opõem as suas opiniões com a exterminação física, inclusive.

A fascistização da sociedade avança. O horror ao pobre, negro, a esquerda em geral, é parte da ideologia. Como assinala Poulantzas (1978, p.105)

Os discursos fascistas não são enunciados num campo fechado da "ideologia em geral", mas sim na articulação das diversas ideologias e subconjuntos ideológicos referentes às classes em luta. Esquecer aqui a luta de classes é privar-se dos meios de situar estas diversas ideologias e ser levado a uma simples descrição pela justaposição dos discursos em questão.

\section{UMA BREVE DEFINIÇÃO DO FASCISMO}

As velhas elites, naturalmente, desprezavam Mussolini, filho de um ferreiro e de uma professora. Ficavam alarmadas com seu aspecto plebeu e sua linguagem rude e populista, mas 
reconheciam nele alguém disposto a se encarregar do trabalho sujo que não sabiam ou não queriam fazer. Certos intelectuais o admiravam abertamente ou não se dispunham a criticá-lo.

Poulantzas, no livro Fascismo e Ditadura, ajuda-nos a compreender, o que significa o processo de fascistização da sociedade. O processo de fascização e a instauração do fascismo correspondem a uma situação de aprofundamento de ajuda a exacerbação das contradições internas entre as classes e frações de classe dominantes: é este um elemento importante da crise política em questão.

Há uma crise da hegemonia: No caso do processo de fascização e do fascismo nenhuma classe ou fracção de classe dominante parece capaz de impor; seja pelos seus próprios meios de organização política, seja por intermédio do Estado «democrático parlamentar» sua direção às outras classes e fracções do bloco no poder. O fascismo

Constitui com efeito, uma forma particular de Estado e de regime, correspondente a uma determinada política da burguesia. Como tal o fascismo corresponde a uma reorganização do conjunto dos aparelhos de Estado, incluindo os aparelhos ideológicos de Estado. Nessa reorganização, um partido de tipo social-democrata não só não pode ter nenhum lugar, mas deve mesmo ser completamente destruído - o que, de fato, acontecerá-, por causa, precisamente, da sua base de massa na classe operária, e na medida em a luta de classes o atravessa: a política da burguesia visa, doravante, o aniquilamento da classe operária (POULANTZAS,1978, p.164).

Poulantzas afirma, mais à frente, que o fascismo é "exógeno" ao aparelho repressivo de Estado. O "instrumento principal de acesso ao poder é um aparelho exterior ao aparelho repressivo de Estado invadido de "fora" (idem, p.358). O fascismo é exógeno, ao aparelho de Estado, mas "consegue penetrar e ganhar esse aparelho do exterior". No entanto, o "fascismo não teria chegado ao poder sem a ajuda decisiva do aparelho repressivo de Estado na luta travada contra as massas populares (...). Não se pode falar no processo de fascização, e seguindo o exemplo de vários social-democratas, de três forças na luta, 'o campo fascista - o Estado - o campo antifascista"” (idem).

Há um processo de fascização na sociedade brasileira, capitaneado pelo governo de Jair Bolsonaro, e, tendo como base uma parte da classe média (aquela que ressuscita o espectro do comunismo $^{\mathrm{x}}$ ) e, parte das classes populares por meio da grande investida das igrejas neopentecostais. O voto evangélico teve um peso importante nas eleições de 2018 e continuam sendo importantes na base de apoio, embora todo seu governo esteja pautado por medidas econômicas e sociais antipopulares. Como se explica essa contradição? Em primeiro lugar, não 
é desprezível o espaço que os neopentecostais ocupam na mídia. Os discursos apocalípticos, a "teologia da prosperidade", e, claro, a difusão de um inimigo, que questiona a sua fé inabalável. Fé esta, que dá alento ao desespero da sua existência. Os discursos e apoios da ala evangélica do cristianismo, não é, todavia, homogênea ${ }^{\mathrm{xi}}$, mas tem mantido a hegemonia.

Com a pandemia, de alguma maneira, estaríamos passando pela experiência teológica do final dos tempos. Nesse sentido, Bolsonaro se encaixa nessa dinâmica apocalíptica. É um governo de muito caos, desconfiança e inconsistência, que responde a esse anseio teológico", afirmou aos jornalistas Marilu Cabañas e Glauco Faria, para o Jornal Brasil Atual. ${ }^{\text {xii }}$

Gramsci, no prefácio a Cartas do Cárcere, assinala que o fascismo não será uma ideologia superadora da democracia liberal, mas sim a sua versão autoritária, que visa o fim da construção nacional através de um Estado italiano mais forte, isto é, totalitário e, portanto, com maior capacidade para impor políticas económicas àqueles sectores críticos com a repartição dos papéis na sociedade italiana. A burguesia usará o fascismo para saldar contas com as forças que colocavam em risco a construção nacional italiana, o socialismo e a Igreja (Prefácio a Cartas do Cárcere). Ignorar que estamos vivendo um momento crucial na sociedade brasileira que pode levar a um recrudescimento do regime, é ignorar todos os elementos que se apresentam nessa conjuntura.

\section{CONCLUSÃO}

A crise da democracia burguesa, representativa, tem sido um nó nas formações sociais capitalistas. No nosso caso: capitalismo periférico/dependente, passagem por uma longa ditadura cívico-militar que, todavia, nos deixa marcas profundas. Não é o caso de discutirmos nesse curto espaço, a larga discussão sobre a transição da ditadura a democracia formal burguesa. O fato é que, defendemos a tese, de que com todos os limites dessa democracia, é ainda, a forma em que há uma possibilidade de organização dos trabalhadores. A consciência de que a democracia burguesa é uma face da ditadura da burguesia, talvez ajude a ampliar o sentido de radicalização da democracia. Por ora, o maior desafio, neste momento, trata-se de agrupar todas as forças progressistas, antifascistas com grande capacidade de diálogo e conseguir quebrar as barreiras e fronteiras que deu hoje sustentação ao governo Bolsonaro e a base do bolsonarismo. Não é tarefa fácil, mas é urgente e necessária. 
BRASIL

\section{REFERÊNCIAS}

CARNEIRO, Henrique Soares. "Rebeliões e ocupações de 2011”. In: HARVEY,

David (et al.). Occupy. São Paulo: Boitempo/Carta Maior, 2012.

CARVALHO, José Murilo de. Cidadania no Brasil. O longo Caminho. $3^{\text {a }}$ ed. Rio de Janeiro: Civilização Brasileira, 2002.

FERNANDES, Florestan. Mudanças sociais no Brasil. São Paulo-Rio de Janeiro: Difel, 1979.

FINLEY, M.I. Democracia antiga e moderna. Rio de Janeiro: Graal, 1988.

FREIRE, Paulo. Pedagogia da autonomia: saberes necessários à prática educativa. São Paulo: Paz e Terra, 1996.

GONZÁLES, Maria Victoria Espiñeira e CRUZ, Danilo Uzêda (orgs). Democracia na América Latina: democratização, tensões e aprendizados. Buenos Aires: Clacso; Feira de Santana: Zarte, 2018.

HALL, Stuart. A identidade cultural da pós-modernidade. Rio de Janeiro, 2000.

HELD, David. Modelos de democracia. Belo Horizonte: Paidéia, 1987.

MARIANO, Ricardo. Sociologia do crescimento pentecostal no Brasil: um balanço. Belo Horizonte: Perspectiva Teológica. Ano 43, Número 119, p. 11-36, Jan/Abr 2011.

MARSHALL, T.H. Cidadania, classe social e status. Rio de Janeiro: Zahar, 1967.

MARX, Karl. O 18 Brumário de Luís Bonaparte. São Paulo: Boitempo, 2011.

POULANTZAS, Nicos. Fascismo e ditadura. São Paulo: Martins Fontes, 1978.

RANCIÈRE, Jacques. O ódio à democracia. São Paulo: Boitempo, 2014.

SAES, Décio. Estado e Democracia: ensaios teóricos. Campinas: Unicamp, 1984. 1985. A formação do Estado burguês no Brasil (1888 a 1891). Rio de Janeiro: Paz e Terra,

SECCO, Lincoln. “As jornadas de junho". In: Cidades rebeldes: passe livre e as manifestações que tomaram as ruas no Brasil. São Paulo: Boitempo/Carta Maior, 2013.

SINGER, André. 2012

SOLANO, Esther e ROCHA, Camila (orgs). As direitas nas redes sociais e nas ruas: a crise política no Brasil.

SOUZA, Jessé e VALIM, Rafael (coords). Resgatar o Brasil. São Paulo: Contracorrente/Boitempo, 2018. 
SOUZA, Jessé. A elite do atraso: da escravidão à lava jato. Rio de Janeiro: Leya, 2017.

WEBER, Max. Ciência e política: duas vocações. São Paulo: Cultrix, 1967.

WOOD, Ellen Meiksins. Democracia contra o capitalismo: a renovação do materialismo histórico. São Paulo: Boitempo, 2003.

\title{
NOTAS
}

\begin{abstract}
i A este respeito, ver Vitor Nunes Leal, Coronelismo, enxada e voto. São Paulo: Alfa Ômega, 1975.
ii Como temos uma baixa participação política, a cidadania reflete essa lógica. Não se forjou aqui a cidadania política. "A tradição de maior persistência acabou sendo a que buscava melhorias por meio de aliança com o Estado, por meio de contato direto com os poderes públicos. Tal atitude seria mais bem caracterizada como 'estadania"”. (CRVALHO, 2002, p.61).

iii Ver Ciência e Política duas vocações. São Paulo: Cultrix, 1968.

iv Jacques Rancière em $\mathrm{O}$ ódio à democracia (2014, p.92) descreve como a democracia foi tolerada e desprezada ao longo dos tempos pela classe dominante. Diz ele: "Toma-se usualmente a existência de um sistema representativo como critério pertinente de democracia. Mas esse sistema é ele próprio um compromisso instável, uma resultante de forças contrárias. Ele tende para a democracia na medida em que se aproxima do poder de qualquer um.
\end{abstract}

v Para esse debate ver: Cidades Rebeldes: Passe Livre e as manifestações nas ruas do Brasil. Publicado pela Boitempo e Carta Maior em 2013

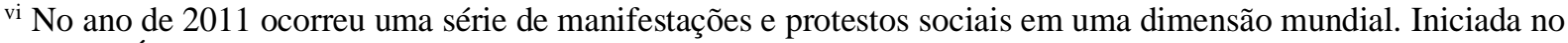
norte da África, derrubando ditaduras na Tunísia, Egito, na Líbia, no Iêmen, alastrou-se á Europa com greves na Espanha, Grécia, Londres, na América Latina (Chile) e também nos EUA. Ver Carneiro, 2012. A diferença do que ocorre no Brasil em 2013 que no nosso entendimento, é tomada pela direita, que encontrou nas ruas, um espaço de luta e protestos.

vii Ou seja, pagos mensais a bancadas na câmara que votassem leis de interesses do governo e o chamado "caixa 2 ".

viii A questão das “identidades" é um tema muito complexo e certeiro. A crítica ao "identitarismo" é que ao enfatizar uma das identidades possíveis: gênero e etnia, por exemplo, desprezam por completo a classe social. Uma leitura que acreditamos ser a mais adequada não deixa de perceber a classe social em que o indivíduo está situado. Para uma discussão mais aprofundada, ver: Asad Haider, Armadilha da Identidade (2019); Lélia Gonzáles "Por um feminismo afrolatinoamericano". (2020); Angela Davis, Mulheres, Raça e Classe (2016) entre tantos outros.

${ }^{\text {ix }} \mathrm{O}$ termo tem origem no nome do senador republicano, estadunidense, Joseph McCarthy, autor de projetos de lei anticomunistas que incentivava a delação de todos que fossem de esquerda. A perseguição política baseada na difamação, no incentivo à prática de acusações de traição ou subversão, publicadas sem evidências, mas com grande impacto negativo na vida dos denunciados.

${ }^{x}$ Difícil identificar até onde há uma adesão deliberada do ponto de vista da propaganda ou se realmente acreditam que o "espectro do comunismo" ronda o Brasil.

xi Das inúmeras denominações evangélicas há dissidências das suas lideranças em relação ao apoio ao presidente; no entanto o discurso hegemônico, capitaneado pela Universal do Reino de Deus e similares continua firme na sua colaboração e apoio.

xii Teixeira, disponível em: https://www.redebrasilatual.com.br/politica/2020/04/governo-bolsonaro-se-encaixaem-narrativa-apocaliptica-segundo-teologa/. Visitado em 13/05/2020). 